\title{
Gun Island: A Tale of Myth, Migration and Climate Change
}

\author{
Ashna Francis \\ Lecturer in English \\ College of Applied Science \\ Kundara, Kerala, India \\ ashnafrancis1417@gmail.com
}

Abstract

Gun Island is a story of travel and migrations, overlaid with myth and folktales, and the deepening crisis of climate change. It presents an intricately interwoven plot which connects human and animal, past and present, natural and the supernatural. This paper attempts to explore how the notion of interconnectedness manifests itself in each of these elements. Gun Island uses the myth of the Gun Merchant as a nexus to draw parallels between the Little Ice Age and our present-day scenario where droughts, floods, cyclones, wildfires and epidemics have become a part of our everyday lives. Gun Island projects unprecedented climatic conditions as the primary cause for these natural disasters. It becomes a clarion call for climate induced migrations as it skillfully portrays people and entire communities being uprooted from their native land and the drastic changes in the migratory patterns of different species due to changing climes and warming waters. Instead of projecting warnings of impending doom and apocalypse Gun Island focuses on giving the readers hope for a better tomorrow.

Keywords: Amitav Ghosh, Climate Change, Illegal Immigrants, Species Migration, Myth and Magic

Climate Change is one of the most important factors that have shaped human history. It can very simply be defined as the long-term shift in global or regional climate patterns. The 
climate of an area includes seasonal temperature, rainfall averages and wind patterns. When there is a long-term altercation in these weather patterns, whether it is confined to a specific place or happens globally, it can be termed as Climate Change. Climate change causes weather patterns to be less and less predictable. This in turn causes great damage to agro communities as expected temperature and rainfall levels can no longer be relied on to grow and maintain crops. Climate change also stands as a primary reason for other destructive weather events such as more frequent and intense hurricanes, floods, downpours, droughts, wildfires and so on.

Since the Industrial Revolution started over 200 years ago, human activities have added very large quantities of greenhouse gases (GHG) into Earth's atmosphere. These GHG act like a greenhouse to trap the sun's energy and heat, rather than letting it reflect back into space. When the concentration of GHG is too high, too much heat is trapped, and the earth's temperature rises outside the range of natural variability. (Center for Climate Change and Health, 2)

This increase in the overall temperature of the earth's atmosphere is termed as global warming. As a result of this, the atmosphere and oceans have warmed considerably leading to the melting of polar ice, massive destruction of coral reefs and unprecedented rise in the sea level. Different habitats and ecosystems are also undergoing rapid alterations with the rapidly shifting climatic patterns. Many ecosystems belonging to diverse endangered species are on the brink of being uninhabitable. Even amidst the pandemic, Climate Change still remains one of the defining issues of our times, as these impacts would only tend to intensify in the coming decades.

The 2020 Global Risks Perception Survey from the World Economic Forum ranked climate change and related environmental issues as the top five global risks likely to occur 
within the next ten years. But even with the importance given to climate change on a global scale and the abundance of scientific information available on the topic, it still remains one of the least discussed areas of literature. This tendency of excluding climate fiction from mainstream writing is more evident in case of Indian literature where most stories related to climate change is branded as improbable and viewed through the lens of disbelief. An Indian author responsible for bringing about a change in this way of thinking and for heralding and popularising the theme of climate change in contemporary Indian English fiction is Amitav Ghosh.

For decades Amitav Ghosh has been writing brilliant fiction portraying human connections across geographical and historical boundaries and within the powerful backdrop of climate change. Almost all his works attempt to disentangle the climate crisis and to promote increased awareness about our planet threatened by various climate related catastrophes. His writing often uses complex narrative strategies and presents meticulously researched facts without losing the interest of the common readers. Ghosh often gives strong emphasis on themes like travel and diaspora, history and memory, political struggle and communal violence, love and loss, and so on. Both his fiction and non-fiction tend to be transcultural in nature, moving swiftly across countries, continents and oceans.

His first novel, The Circle of Reason (1986), follows an Indian protagonist who, suspected of being a terrorist, leaves India for northern Africa and the Middle East. His next novel, The Shadow Lines (1988) portrays the stories of two families, one Indian and the other English, who were affected by the departure of the British from India in 1947. The Circle of Reason and The Shadow Lines, both written in English, were widely translated and gained Ghosh an international readership.

His subsequent novels included The Glass Palace (2000), a familial history centred on Burma and The Hungry Tide (2004), set in Bengal and featuring American and Indian 
characters. Ghosh pioneered his Ibis trilogy with Sea of Poppies (2009), a novel that describes individuals on the Ibis, a ship carrying indentured labourers and opium. This historical series also included River of Smoke (2011) and Flood of Fire (2015).One of his most influential and powerful pieces of nonfiction about climate change is The Great Derangement: Climate Change and the Unthinkable(2016). In 2007, Ghosh was awarded the Padma Shri, one of the most celebrated awards in India, for his distinguished contribution to literature.

This paper attempts to explore how the notion of interconnectedness manifests itself in one of Ghosh's recent novels, Gun Island. It "is a story of travel and migrations, overlaid with myth and folktales, and the deepening crisis of climate change" (Ians). It presents an intricately interwoven plot which connects human and animal, past and present, natural and the supernatural. This striking coexistence of unrelated elements even extends to instances where myth and magic blends effortlessly with events related to climate change.

Gun Island tells the story of Dinanath Datta(Deen), a rare book dealer, who has settled in Brooklyn and is of Bangladeshi heritage. The story begins with Deen visiting Kolkata in order to escape the bitter winter of Brooklyn. While attending a party in Kolkata Deen is confronted by a distant relative who tells him an uncommon version of a story very familiar to Deen. It is a tale that has been passed down through generations as an old Bengali folklore and is about Chand Sadagar, a merchant and Manasa Devi, the Goddess of snakes and other poisonous creatures. It presents the battle undertaken by Manasa Devi to turn Chand Sadagar into her devotee and his adamant refusal to pay her homage.

The Gun Merchant is forced to leave his home as he loses his wealth and his family in his tussle with the goddess. Still pursued by the Devi while on his travels, the merchant is captured by pirates, sold as a slave, then freed by his master, finds a treasure trove of cowries -- the shells used as currency in the 
Indian Ocean coastal region --, and reaches Venice, the great trading port of the 17th century. The Mediterranean is going through unseasonal weather with storms and devastating floods that came to be known as the little ice age. The merchant is forced to return to Bengal to make peace with the goddess and build her a temple which protects the local villagers till it is swept away by the rising waters and frequent storms that ravage the Sundarbans in the 21st century. (Ians)

But the version of the story told by his relative addresses Chand Sadagar as 'BondukiSadagar' or'the Gun Merchant'. Bundook in Bangla means gun and the search for the etymology of the name 'BondukiSadagar' launches Deen on a global quest, before he finally solves the mystery. This unexpected retelling of the story leads Deen to visit an ancient temple hidden in the mangrove swamps of the Sundarbans. His journey unfolds a series of events, that beautifully portrays the present reality of climate change and disruptive migratory patterns of both humans and animals induced by it.

Gun Island explores different forms of migration, starting from people and entire communities being uprooted from their native land to the drastic changes recently prevalent in the migratory patterns of different species. Ghosh gives many instances of climate related catastrophes being inductors of such migrations. He talks in detail about the cyclone Aila which hit the Sundarbans in 2009.

Aila's long-term consequences were even more devastating than those of earlier cyclones. Hundreds of miles of embankment had been swept away and the sea had invaded places where it had never entered before; vast tracts of once fertile land had been swamped by salt water, rendering them uncultivable for a generation, if not forever.The evacuations too had produced effects that no one could have foretold. Having once been uprooted from their villages 
many evacuees had decided not to return, knowing that their lives, always hard, would be even more precarious now. Communities had been destroyed and families dispersed ... (Ghosh 48)

The increasingly impoverished state of the Sundarbans had made it a haven for traffickers especially after the devastating effects of the Cyclone Alia. The people of Sundarbans are accustomed to living in tune with nature following traditional occupations like fishing. But with the rapidly changing terrain of the Sundarbans and recurring natural calamities like cyclones and intense storms, it seems as if the land and waters that they had known all their lives were no longer the same. Rivers treacherously changing course and constant flooding swallowing up more and more of the land has left even the most experienced fisherman perplexed to navigate the waters. People are being forced to migrate in large numbers as life in the Sundarbans becomes increasingly difficult and unpredictable.

There are also people like Tipu and Rafi who choose to leave for entirely different reasons. Rafi is a young fisherman who guards the temple of Manasa Devi and Tipu is a tech genius who helps people migrate to other countries in search of a better life. Both Rafi and Tipu assist Deen in unravelling the puzzle of the Gun Merchant. Both of them live in a world where they don't have a sense of belonging. Having been educated abroad and being accustomed to an affluent lifestyle, Tipu finds it harder everyday to be part of an impoverished and superstitious community. Rafi on the other hand feels that he has no choice but to leave if he wants to experience true freedom. The last of his family is dead and the temple that has been a proud heritage for him is close to being completely ruined. He doesn't have any roots tying him down and with the repeated natural calamities affecting the Sundarbans on a regular basis he knows that building a future there is nearly impossible. Rafi repeats his grandfather's words almost as a foreshadowing of his impending migration. "He'd tell me that I didn't need to learn what he knew because the rivers and the forest and the 
animals are no longer as they were. He used to say that things were changing so much, and so fast, that I wouldn't be able to get by here - he told me that one day I would have no choice but to leave" (Ghosh 86).

Ghosh maintains this motif of migration, especially climate induced migration, throughout the novel, whether in case of humans or animals. Creatures like spiders, snakes, dolphins and even shipworms are shown in unfamiliar and unexpected habitats as differences in temperature and humidity disrupts their migratory patterns. An incident involving yellow bellied snakes washing up in the shores of Venice Beach is one example of such migrations."These snakes generally lived in warmer waters, to the south, but sightings in southern California had become increasingly common: their distribution was changing with the warming of the oceans and they were migrating northwards" (Ghosh 134). Another creature exhibiting unnatural migratory behaviour is the brown recluse, a kind of venomous spider with an extremely painful bite."The brown recluse has been increasing its range very quickly because it's getting so much hotter in Europe" (Ghosh 204). Gun Island becomes a clarion call for climate induced migrations as it skillfully portrays migrations in different species due to changing climes and warming waters.

Piya, researcher in marine biology, is a Bengali American teaching in Oregon and is sort of an adoptive mother for Tipu's family. She becomes an authoritative voice on Gun Island and addresses environmental crises like 'dead zones' and the rapidly changing migratory patterns of aquatic animals. Dead zones are vast stretches of water that has too low oxygen content for fishes to survive. Large amounts of residues from factories and chemical fertilisers are being dumped into water bodies leading to phenomenal growth of these dead zones. Though they are mostly spread over thousands of miles in the oceans, nowadays these dead zones have started appearing in rivers too. This is more noticeable in case of Indian rivers where there is massive discharge of agricultural effluents and untreated chemicals from 
nearby factories and refineries. This leads to a phenomenon called massive fish kill. "It's when you find thousands of dead fish floating on the surface or washed up ashore. It's happening all round the world with more and more chemicals flowing into rivers" (Ghosh 96).

Though many scientific discussions related to climate are foregrounded in Gun Island, Ghosh still succeeds to maintain an aura of myth and magic throughout the novel. During Deen's visit to the temple of Manasa Devi, Tipu gets bitten by a cobra. Even though his life is saved, this incident sets forth a chain of uncanny events starting from Tipu's vision about Rani, a dolphin that was beached. Even after returning to Brooklyn Deen is unsettled and has difficulty forgetting the tale of the Gun Merchant and the interesting puzzle behind the etymology of that name. A feeling of anxiety envelops Deen for many months after returning to Brooklyn. It is only when he gets a chance to meet up with Cinta, a Venetian history professor and also his mentor, that he shows some sign of returning to his old self. Cinta invites him to come to Los Angeles to celebrate the acquisition of a very valuable and rare seventeenth century edition of The Merchant of Venice by a museum.

Ghosh uses Deen's journey to Los Angeles to highlight yet another natural calamity, the raging fires of Los Angeles. According to reports, 2018 was California's worst year of repeated wildfires ever. Ghosh has drawn inspiration from this while portraying the wildfirerazing Los Angeles during Deen's visit. Deen could see the incinerated landscape from his seat in the plane itself. Hillsides and forests had been so completely laid to waste that it looked like a "vast field of ash" (Ghosh 116). The conference at Los Angeles begins with an opening speech made by a trendy young historian with a hipsterish appearance, about 'Climate and Apocalypse in the $17^{\text {th }} \mathrm{c}$ '.

The seventeenth century, declared the historian, was a period of such severe climatic disruption that it was sometimes described as the 'Little Ice Age'. 
During this time temperatures across the globe had dropped sharply, maybe because of fluctuations in solar activity, or a spate of volcanic eruptions ... In any event many parts of the world had been struck by famines, droughts and epidemics in the seventeenth century. At the same time a succession of comets had appeared in the heavens, and the earth had been shaken by a tremendous outbreak of seismic activity; earthquakes had torn down cities and volcanoes had ejected untold quantities of dust and debris into the atmosphere. Millions had died: in some parts of the world the population had declined by a third. (Ghosh 122)

Deen on hearing this suddenly recalls the droughts, famines, storms and plagues that followed the Gun Merchant as he travelled round the globe to escape the wrath of Manasa Devi. A new notion enters his mind that the legend might have been born of the tribulations of the Little Ice Age. Ghosh through the words of the historian tactfully connects the myth of the Gun Merchant and the Little Ice Age with the perilous and unpredictable climate of the 21 st century. He uses the myth of the Gun Merchant as a nexus to draw parallels between the Little Ice Age and our present-day scenario where droughts, floods, cyclones, wildfires and epidemics have become a part of our everyday lives.

Ghosh draws parallels not just between the past and the present but also between two completely different geographical zones and communities. The marshy flood prone Sundarbans of West Bengal is connected with the city of Venice in Italy which is slowly sinking. Both these places are unique environmentally and are known to be famous tourist destinations. The Sundarbans is a cluster of low-lying islands famous for its unique mangrove forests and diverse wildlife including endangered tigers, dolphins and crocodiles. But lately these remote islands are getting international attention for an altogether different reason. Islands in Sundarbans are disappearing due to rising waters destroying the natural habitat of 
many species and forcing many natives to relocate to new and unfamiliar surroundings. Islands like New Moore and Lochachara has been completely submerged while others like Ghoramara are shrinking with alarming speed. So, it can be said that the Sundarbans are bearing the brunt of the climate crises in India. Rising sea levels and aggressive cyclones also lead to more and more saltwater flooding in agricultural areas deeming them unsuitable for any crop yield.

The lagoon city of Venice too consists of a series of islands separated by canals with about four hundred bridges linking them. Its historic buildings crisscrossed by these canals lack proper foundations and are gradually sinking into the waters of the lagoon. The impact of climate change on Venice is becoming more visible nowadays as the frequency of flooding from acquaalta(exceptionally high tides combining with strong winds and a storm) also increases.

The water levels are now permanently above the original damp proof courses of older homes and buildings in the city. Saltwater attacks the friable clay bricks causing them to crumble and let in more water. As a result, the ground floor of many of Venice's buildings are now uninhabitable. To preserve them and prevent more erosion, underwater barriers have been installed to reduce the quantity of water entering the lagoon. (Eaglescliffe)

While Ghosh sketches Deen's journey from the Sundarbans to Los Angeles and from there to Venice, he doesn't just portray a protagonist solving the riddle behind the origin of a popular myth. Rather he takes the reader on a journey along with Deen clearly showcasing the climatic catastrophes ravaging the different countries around the globe that Deen visits. Deen's friend Cinta gives the closing address of the conference that he attended in Los Angeles. She describes Venice as 'an island within an island' and Deen remembers Rafi using the same words to describe the last place that the Gun Merchant stayed while travelling 
around the world to escape the wrath of Manasa Devi. Cinta also talks about the etymology of the name 'Venice', "through Arabic the name of Venice has travelled far afield, to Persia and parts of India, where to this day guns are known as bundook - which is, of course, none other than "Venice" or "Venetian"!" (Ghosh 137). It suddenly dawns on Deen that 'BondukiSadagar' might not mean 'the Gun Merchant' but rather the 'The Merchant who went to Venice'.

This new information causes Deen to travel to Venice where he encounters extreme climatic cataclysms,struggles faced by illegal immigrants and unprecedented instances of animal migration. Ghosh paints Venice as a microcosm of our world today by depicting the different natural disasters occurring there one after another. First, there was flooding and hightides due to the acquaalta. Then the very next day, strong winds and a hailstorm of such intensity as never seen before appeared, which was followed by a tornado. There used to be a time in the past when such recurring calamities would only be found in the pages of fiction and would be considered unrealistic. But today our climate has become so completely unravelled that it can easily become a reality.

Cinta becomes Deen's partner in solving the rest of the puzzle about the Gun Merchant and his companion during his stay in Venice. She transforms the myth of the Gun Merchant and recasts the events in it in a historically plausible manner. Deen meets another unlikely acquaintance in Venice, Rafi, who has come to Venice as a migrant worker. By describing Rafi's journey to Venice and his life there Ghosh brings to light the struggles that illegal immigrants have to undergo while moving across countries. Rafi had started the journey to Venice along with Tipu but they got separated while crossing the Turkish border. By discussing the stories of such migrants Ghosh foregrounds topics like connection houses where many migrants have to stay for weeks or months in inhuman conditions, local 'dalals' 
who exploit them for money, and worst of all, the fact that they might be fatally hurt if they run out of money at any point in the journey.

Gun Island ends with the introduction of a new trope, the Blue Boat, a boat full of refugees stranded in the Eastern Mediterranean. They were stopped from approaching Italy and many other countries in the Mediterranean also sent coastguards to stop them from entering their premises. According to Palash, a Bengali immigrant, the Blue Boat "has become a symbol of everything that's going wrong with the world - inequality, climate change, capitalism, corruption, the arms trade, the oil industry. There's a lot of hope that this will be a historic moment. Maybe now, while there's still time to make changes, people will wake up and see what's going on" (Ghosh 199). Deen and Cinta becomes part of the human right activists who decides to take civilian vessels to support the refugees. Piya and Rafi too join this expedition as they receive information that Tipu might be in the Blue Boat. Thus, the Blue Boat becomes a connecting point that brings together all the central characters of the novel towards the end.

Ghosh tactfully links the climax of the novel to the myth of the Gun Merchant. By doing so he foregrounds how myths and legends of our past always hold a place in our present. The Gun Merchant after leaving Venice was taken captive by pirates. They were taking him to be sold as a slave on the 'Island of Chains' or 'Shikoldwip'. The legend says that on the way to the Island, there is a miracle and the Gun Merchant is saved by the creatures of the sky and the sea. Cinta explains how the Arabic name for Sicily is 'Siqillia', which sounds very much similar to 'Shikol'. She believes it is possible that the merchant was going to Sicily when the miracle happened. The Blue Boat is also headed towards the same destination at the end of the novel. And just as a miracle saved the Gun Merchant, the refugees in the Blue Boat too are saved by an unlikely event. Schools of dolphins and whales belonging to almost all Mediterranean species came together and was seen circling the boat, 
creating a barrier to the approaching warships. Millions of birds migrating northwards too became a part of this scene and presence of bioluminescence was seen around the boat.

The colour of the water around the refugee boat began to change. In a few moments it was filled with a glow, of an unearthly green colour, bright enough that we could see the outlines of the dolphins and whales that were undulating through the water ... we were transfixed by this miraculous spectacle: the storm of birds circling above, like a whirling funnel, and the graceful shadows of the leviathans in the glowing green water below (Ghosh 282).

Just like in the legend the creatures of the sky and sea rose up to protect these migrants. This event prompted the Admiral in charge of the warship to give an order for the rescue of the migrants, which he thought was "in accordance with the law of the sea, the law of humanity and the law of God" (Ghosh 285).Ghosh takes up "a series of migratory pattern intersecting in an unusual way" (Ghosh 284) and creates a spectacularly humane and inexplicable scenario out of it.

Gun Island as opposed to many other tales of climate change ends on a happy note as the migrants are safely rescued and Deen and Piya comes to an understanding and decides to take a chance to be together. Even Cinta's sudden death at the end doesn't strike as a tragedy but rather as a long-awaited reunion with her deceased family.Throughout the novel Ghosh succeeds in maintaining a positive outlook. Instead of projecting warnings of impending doom and apocalypse he gives the readers hope for a better tomorrow. 


\section{Works Cited}

Center for Climate Change and Health. Climate Change 101: climate science basics.climatehealthconnect.org, 2016, climatehealthconnect.org/wpcontent/uploads/2016/09/ Climate101.pdf.

Eaglescliffe, Beth. "Venice, Italy, Is Being Destroyed by Tourism and Flooding." Wander Wisdom, 17 Aug. 2021, wanderwisdom.com/travel-destinations/Venice-TourismSinking.

Ghosh, Amitav. Gun Island. Penguin Random House India, 2019.

Ians. "Amitav Ghosh unveils the 'Magic of the Bonduki' in his latest book 'Gun Island."' The New Indian Express, 2 Jul. 2019, www.newindianexpress.com/lifestyle/books/2019/jul/02/amitav-ghosh-unveils-themagic-of-the-bonduki-in-his-latest-book-gun-island-1998333.html.

Maslin, Mark. Climate Change: A Very Short Introduction. $3^{\text {rd }}$ ed., Oxford UP, 2014. 